http://kitaibelia.unideb.hu/

ISSN 2064-4507 (Online) • ISSN 1219-9672 (Print)

(C) 2015, Department of Botany, University of Debrecen, Hungary

21 (1): 33-50.; 2016

DOI: $10.17542 /$ kit.21.33

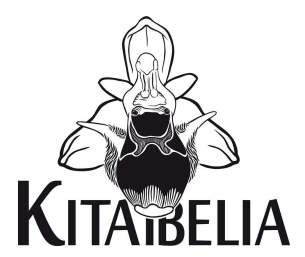

\title{
Adatok Budapest környéke flórájának ismeretéhez II.
}

\author{
SOMLYAY Lajos ${ }^{1}$, MAKÁDI Sándor² \& CSÁBI Miklós ${ }^{3}$
}

(1) MTM Növénytár, H-1431 Budapest, Pf. 137.; somlyay@bot.nhmus.hu

(2) H-1046 Budapest, Bőröndös u. 18.

(3) H-1035 Budapest, Kerék u. 4.

\section{Contributions to the flora of Budapest and its surroundings II.}

\begin{abstract}
New and recently confirmed localities of 52 rare taxa (including 26 orchids) are presented from the vicinity of Budapest. Epipactis peitzii is a new species for the Hungarian flora; it has been recorded in the Buda and Pilis Mts. This species and its closest relatives (E. leptochila group) are briefly discussed. Other records are new for the flora of particular regions, specifically: Buda Mts: Corydalis intermedia, Epipactis leptochila, Epipactis muelleri; Pilis Mts: Anacamptis coriophora, Epipactis neglecta, E. tallosii, Valerianella pumila; Visegrád Mts: Epipactis futakii, E. leptochila, E. muelleri, E. neglecta, Ophrys apifera, 0 . holubyana.
\end{abstract}

Keywords: Buda Mts, Epipactis peitzii, flora, orchid, Pilis Mts, Visegrád Mts

Összefoglalás - Cikkünk 52 ritka taxon (köztük 26 orchidea) új vagy megerősített florisztikai adatait tartalmazza Budapest környékéről. Közülük egy faj (Epipactis peitzii) új Magyarország flórájára, a Budai-hegységből és a Pilisből került elő. Röviden jellemezzük, összehasonlítva a legközelebbi rokon fajokkal (E. leptochila csoport). További három faj (Corydalis intermedia, Epipactis leptochila, Epipactis muelleri) a Budai-hegység flórájára, négy (Anacamptis coriophora, Epipactis neglecta, E. tallosii, Valerianella pumila) a Pilis flórájára, hat (Epipactis futakii, E. leptochila, E. muelleri, E. neglecta, Ophrys apifera, 0 . holubyana) pedig a Visegrádi-hegység flórájára új.

Kulcsszavak: Budai-hegység, Epipactis peitzii, flóra, orchidea, Pilis, Visegrádi-hegység

\section{Bevezetés}

Közleményünkben, a hasonló címmel megjelent dolgozat (SomLYAY 2011b) folytatásaként, az elmúlt években a magyar fóváros környékén észlelt fontosabb florisztikai adatainkat adjuk közre. Közöttük hangsúlyosan szerepelnek orchidea-adatok, olyanok is, amelyek MoLNÁR (2011a) atlaszának áttekintő ponttérképein már megjelentek, de lelőhelyük formális közlésére ez ideig nem került sor. Az enumerációban a fajok abc-rendben következnek. A KEF-kóddal ellátott előfordulásokat Budapest szűkebb környéke („B”, ez alatt értve Budapest alföldi területeit, a Budai-hegységet és a Tétényi-fennsíkot), a Pilis („P”, ide értve a szűkebb értelemben vett Pilis hegységet a Pilisi-híd hegycsoporttal, és a sátorkőpusztai homokbányát) és a Visegrádi-hegység („V”) sorrendjében, ezeken belül közigazgatási egységek szerint csoportosítottuk. Adataink túlnyomó többségét herbáriumi példánnyal dokumentáltuk az MTM Növénytárában és a DE herbáriumában. Régebbi herbáriumi vagy irodalmi adat megerősítése esetén zárójelben feltüntettük az általunk ismert első forrást (a gyűjtő nevét dőlt, a publikáció szerzőjét kiskapitális betűtípussal szedve), esetenként többet 
is. Ha a régi és az új lelőhely azonossága nem egyértelmű, vagy közeli, de föltehetően nem azonos lelőhelyekről van szó, a régi lokalitást is feltüntettük. A citált herbáriumok akronímjai: BP - MTM Növénytára, BPU - ELTE Füvészkertje, CORV - Corvinus Egyetem (Budapest), DE - Debreceni Egyetem, GYÖ - Mátra Múzeum (Gyöngyös), SAU - Kazinczy Ferenc Múzeum (Sátoraljaújhely), SZE - Móra Ferenc Múzeum (Szeged), SZIE - Szent István Egyetem (Gödöllő).

\section{Enumeráció}

Anacamptis coriophora (L.) R.M. Bateman, Pridgeon \& M.W.Chase (Orchis coriophora L.) P: Pilisszentkereszt: Pilis-hegy alatti földek [8379.1].

Új adat a Pilis hegység flórájára (vö. BoRSos 1962, Soó 1973, MátHÉ et al. 2011). Miután a RAKSÁNYI (1999) által felfedezett, az elmúlt években többször is kutatott, aránylag kis, méhbangós területen bukkantunk rá egyetlen virágzó tőre, bizonyosan új megtelepedés. Legközelebb a Visegrádi-hegységben gyűjtötték („Sikáros”, Boros, Pénzes, Priszter, 1948, BP, BPU), illetve a Budai-hegység és a Kisalföld határán lévő piliscsabai lőtér széléről közölték (DoBOLYI et al. 2008). A bizonytalan esztergomi lelőhely - BAUER \& BARNA (1999) közlik, BAUER (1996, 2001) azonban nem, MáTHÉ et al. (2011) ponttérképe pedig csak egy 19. századi adatot („Dorogh”, Grundl, SZE) jelöl - továbbá a régi, szentendrei, békásmegyeri és óbudai előfordulások (KERNER 1877a, BORBÁs 1879) a növényföldrajzi értelemben vett Alföldhöz tartoznak.

Anacamptis morio (L.) R.M. Bateman, Pridgeon \& M.W.Chase (Orchis morio L.) - P: Budakalász: Ajmanica [8380.3], Monalovác-hegy [8380.3]; Csobánka: Bükk-lyuk [8379.2], Oszoly-erdő [8379.4] (Zsák, 1932, CORV); Esztergom: Csurgó-hegy [8278.4], Kis-Strázsahegy [8278.1, 8278.3], Nagy-Strázsa-hegy [8278.4] (Grundl, 1868, SZE), Nagy-Strázsahegytől ÉK-re lévő domb [8278.4], Öreg-szállás [8278.4], Tetves-kút [8278.4]; Pilisszentkereszt: Pilis-hegy alatti földek [8379.1] („Pilishegy”, Vajda, 1928, BP); Pomáz: Majdán [8379.4]. - V: Dömös: Prépost-hegy [8279.1] (Horánszky, 1954, BP); Dunabogdány: Csepri-hegy (Sajgó) [8280.1], Csódi-hegy [8280.1] (Barina \& Pifkó, 2002, BP), 228 m-es domb a Csódi-hegytől DNy-ra (Rókahegyi-dúlő) [8280.1], Körös-hegy [8280.1], Kutya-hegy [8280.1], Len-hegy [8280.1], Pálócki-rét [8280.3]; Esztergom: Cigány-kúttól ÉK-re [8278.2]; Leányfalu: Szarvas-szérű [8280.3] (Degen, 1918, BP); Pilisszentlászló: Bükkös [8279.4] („Pilisszentlászló”, Zsák, 1918, CORV); Delmár-kúti-dúlő [8279.4], 425 m-es hegy a Delmár-kúttól D-re [8279.4], Öreg-Pap-hegy [8279.4], Sikárosirét [8279.4] (Tuzson, 1907, BP); Pomáz: Gyopár-forrás közelében [8379.2] (Gotthárd, 1975, GYÖ), Kis-Csikóvár [8379.2], Kő-hegy [8380.1] (Degen, 1920, BP), Messelia [8380.1]; Szentendre: Anna-völgy [8380.1] (Boros, 1918, BP), Jegyző kertje [8280.3], Kapitány-hegy [8280.3], Kis-kő-hegy [8380.1], Macska-lyuk [8280.3], Mária-fülke [8380.1], Nyerges-hegy [8280.3] („Leányfalu fölött”, Boros, 1916, BP), Száraz-pataki őrháztól D-re [8380.1], Szmerdán-dűlő [8380.1] („Izbég”, Degen, 1916, BP, „Kő-hegy”, Degen, 1920, BP), Szűcs-tanya [8380.1]; Tahitótfalu: Cseresznyés-völgy [8280.1], Farkasrét [8280.1], Hegyesd [8280.1], Nádas-tói-rét [8280.1], Vértes-mező [8280.3] („Öregbükktető”, Jávorka, 1918, BP, Gotthárd, 1969, GYÖ), Zánkói-rét [8280.3] („inter montes Szent László et Öregbükk-t.”, Pócs, 1944, BP); Visegrád: Dobos-hegy [8279.2], Fekete-hegy [8279.2] (Szépligeti, 1889, BP), Kis-Disznó-hegy [8279.4], Kis-Villám [8179.4], Mogyoró-hegy [8179.4, 8180.3], Nagy-Villám [8279.2] (Priszter, 1948, BPU).

A Pilis hegység Dorog környéki részéről régóta ismert, BAUER $(1996,2001)$ és BAUER \& BARNA (1996) is jelzik. Saját esztergomi adataink kiegészítések, ill. pontosítások ezen dolgozatokhoz. Habár a Visegrádi-hegységben általánosan (jóllehet szórványosan) elterjedt faj (vö. MoLNÁR 2011c), alig van publikált adata innen. 
Anacamptis pyramidalis (L.) Rchb. - B: Budapest: Felső-Kecske-hegy [8479.4, 8480.1, 8480.3] („Felső-Kecske-hegy”, Degen, 1925, BP; ez a helynév Degen korában a mai AlsóKecske-hegyre vonatkozott), Hármashatár-hegy [8480.1] (Zsák, 1916, CORV), Kőtaraj [8480.3], Tábor-hegy [8480.3], Újlaki-hegy és Hármashatár-hegy közti nyereg [8479.2]; Nagykovácsi - Perbál: 471 m-es csúcs környéke [8479.1] („Nagykovácsi versus Tinnye”, Jávorka, 1937, BP), Szerdahelyi-vágástól Ny-ra [8478.2], Széna-hegy [8479.1]. - P: Budakalász: Majdán-hegy [8379.4]; Csobánka: Ziribártól ÉNy-ra lévő domb [8379.2]; Esztergom: Nagy-Strázsa-hegytől Ny-ra lévő domb [8278.3] („Strázsa-hegy”, BAUER 1996); Pilisszentkereszt: Pilis-hegy alatti földek [8379.1] („in monte Pilis”, Degen, 1900, BP). - V: Esztergom: Cigány-kúttól ÉK-re [8278.2].

Jóllehet HEGEDÜs (1994) a főváros területén nem észlelte, a fajnak a Budai-hegységből számos herbáriumi és irodalmi (pl. MAKOWSKY 1855, KERNER 1877b, BORBÁs 1879, PAPP 1977, SZERÉNYI \& KÁllAY 2000, DoBOlYI et al. 2008, TóTH \& PAPP 2012) adata ismert. A Pilisből jóval kevesebb előfordulása dokumentált, a Pilis hegy környékéről BőHM \& FACSAR (1999) nem jelzik. Új adataink közül kiemeljük a csobánkai és esztergomi lelőhely százas nagyságrendű populációját. Esztergom környékéről BARINA \& PIFKó (2007) is közlik.

Androsace maxima L. - B: Budaörs: Odvas-hegy [8579.2] (Moldvai, 1964, BP), Törökugrató [8579.2].

A herbáriumi példányok tanúsága szerint ez a löszös gyepekre, ill. szegetáliákra jellemző faj egykor jóval gyakoribb volt a főváros környékén. Mára országszerte erősen megfogyatkozott, ezért fokozottan veszélyeztetett (PINKE \& PÁL 2005). Habár ritka, lokálisan tömeges lehet, mint az a fenti lelőhelyeken is mutatkozott 2004-ben. Budaörs környékéről régóta ismert, de a gyűjtőhelyek többnyire pontatlanok, csak a települést jelzik (Bohatsch, 1877, BP, Szombathy, 1908, BP, Boros, 1926, BP, Pénzes, 1948, BP), vagy esetleg a „Csíki-hegyek”-re korlátozhatók (Máthé 1952, BP, Hegedüs, 1984, BP). Kivételt képez Moldvai Rezső odvashegyi adata, amelyet azonban az utóbbi fél évszázadban nem erősítettek meg (vö. DoBOLYI et al. 1991). Kun (1994) a Huszonnégyökrös-hegyen találta.

Aquilegia vulgaris L. (s. 1.) - P: Piliscsaba: Kis-Széna-hegy [8379.3].

Spontán előfordulása a budai-hegységi Szénásokról régóta ismert (Simonkai, 1874, BP, vö. SoÓ \& ENDRŐDY-KovÁCS 1966, SOMLYAY 2009: 54), és valószínű, hogy SADLER (1840: 221) piliscsabai adata (cit. BoRBÁs 1879: 246) is innen származik. A Pilisben bizonyíthatóan eddig egyetlen helyről került elő (Pilisszentlélek: Fekete-kő, FEICHTINGER 1865, Boros, 1928, BP). Területünkön a dolomithoz kötődő montán reliktum, néha azonban kertekből is kiszökik.

Brassica elongata Ehrh. - B: Biatorbágy: Kő-hegy [8579.1]; Diósd: Kőbánya [8579.4]; Érd: Fundoklia-völgy [8679.1]; Páty: Kecskés [8578.2], Pince-hegy [8478.4]; Sóskút: Nagyhegy [8579.3], Nagy-mező [8579.3].

Budai-hegységi adatait Somlyay (2009) foglalja össze. A Tétényi-platón helyenként gyakori faj, de publikált adatainak száma kevés. A biatorbágyi Iharos-erdőből, ill. környékéről KÁRPÁTI (1947), a Százlépcső-hegyről Kun (1996b), a sóskúti Fundoklia-völgyből Kun (1998) jelzi. A plató populációi dél-délnyugat felé az etyeki-dombsági és az észak-mezőföldi állományokhoz kapcsolódnak. SzERÉNYI (2000) többek között az érd-ófalui Kakukk-hegyről és az érd-százhalombattai földsáncról közli, az Etyeki-dombság szélén Somlyay a biatorbágyi Bolha-hegyen és a sóskúti Kálvária-hegyen gyűjtötte (BP). Szerényi Júlia az érdi Fundokliavölgyben is észlelte (in litt.).

Bupleurum longifolium L. - P: Piliscsaba: Kis-Széna-hegy [8379.3].

Az Aquilegia vulgaris-hoz hasonlóan e montán faj is a budai-hegységi Szénások és a pilisi Zajnát-hegyek florisztikai rokonságát (vö. BoROS 1953) domborítja ki. A Pilis-Visegrádihegységben igen ritka, biztos adata eddig csak a Pilis hegyről és a Dobogókőről volt ismert (vö. SOMLYAY 2009: 54). Bőhm Éva (ex verb.) is megtalálta „Klotildliget mellett”. 
Cephalanthera rubra (L.) Rich - B: Budapest: Budakeszi-erdő - Virág-völgy [8479.4] („In querceti Budaköz", Haberle ?, s. d., BP, sub E. microphylla), Sváb-hegy [8579.2] („Schwabenberg”, Dorner, 1849, BP), Zugliget [8479.4] („Sauwinkel”, Heuffel, s. d., BP); Nagykovácsi: Cseresznyés-erdő [8479.1], Remete-szurdok, [8479.2], Széna-hegy és Forrás-dűlő között [8479.1], Vörös-pocsolyás-hát [8479.1]; Solymár: Kerek-hegy [8479.2]; Telki: Széltörés-erdő [8479.1], Vasvári-erdő [8479.1]. - P: Csobánka: Ziribár [8379.4] („Csobánka”, Zsák, 1928, CORV); Esztergom: Fekete-hegy (Pilis-nyeregtől ÉNyra) [8279.3]; Pilisborosjenő: Magas-erdő [8379.4]; Pilisszántó: Pilis [8379.1] (Grundl, 1864, SZE), Som-hegy és 386 m-es domb közti völgy [8379.1]; Pilisszentkereszt: Hármasforrás-völgy [8279.3] - V: Esztergom: Hág-hegy [8278.2]; Tahitótfalu: Leány-kút Ugró-patak völgye [8280.3].

Rejtőzködő, az évi hajtások számában igen nagy ingadozást mutató faj (MoLNÁR 2011b), kevés publikált aktuális adattal. Területünkön - a Visegrádi-hegység kivételével - általános, de igen szórványos előfordulású (vö. BoRSOS 1959, MOLNÁR 2011b).

Ceratocephala testiculata (Crantz) Roth - B: Budaörs: Odvas-hegy [8579.2], Út-hegy [8579.2].

Országosan ritka faj (SIMON 2000). Budaörs környékéről főként régi és pontatlan lelőhelyű példányokat ismerünk (Borbás, 1871, BP, Szombathy, 1908, BP, Pénzes, 1948, BP), a Törökugratón Gotthárd Dénes szedte 1973-ban (GYÖ, vö. BÁNKUTI 2000). DoBolYI et al. (1991) nem jelzik.

Conringia austriaca (Jacq.) Sweet - P: Csobánka: Hosszú-hegy (475 m-es csúcs környéke) [8379.2], Kerekes-hegy [8379.4].

Növényföldrajzilag igen jelentős faj, amelynek hazai adatait SOMLYAY (2011a) tekinti át; a fentiek kiegészítések az eddig ismert pilisi lelőhelyekhez.

Coronilla coronata L. - B: Budakeszi: Sorrento-tól É-ra [8579.2]; Budaörs: Kecske-hegy [8579.1], Út-hegy [8579.2]; Budapest: Budakeszi-erdő [8479.4], Diós-árok [8479.4], Harang-völgy [8479.4] (SzolLát 2007), János-hegy [8479.4] (Sztehlo, 1875, BP); Perbál: 471 m-es csúcs környéke [8478.2, 8479.1]. - P: Csobánka: Kerekes-hegy [8379.4], ÖregCsobánka [8379.4] (Barina \& Pifkó, 2001, BP); Pilisborosjenő: Magas-erdő [8379.4]; Piliscsaba: Kis-Széna-hegy [8379.3] („Piliscsaba”, Tuzson, 1909, BP); Pilisszántó: Hosszúhegy [8379.1], Üröm: Kő-hegy [8380.3].

A fentiek pótlások SomlYay $(2009,2011 b)$ dolgozataihoz, kiegészítve Szollát (2007) korábbi adatával, amelyik az első áttekintésből kimaradt.

Corydalis intermedia (L.) Mérat - B: Piliscsaba: Hárs-hegy [8379.3], Kis-Szénás É-i alja [8379.3]; Pilisszentiván: Hárs-erdő [8379.3]. - P: Piliscsaba: Kis-Széna-hegy [8379.3].

Új a Budai-hegység flórájára (Soó 1968, SimON 2000). Jóllehet az MTM Növénytárában található egy 1880-ban gyűjtött lap, amelynek céduláján „in montis silv” és külön „Budae” szavak olvashatók, a kézírás a Vas megyei tudós tanítóé, Márton Józsefé, aki bizonyára csere révén jutott hozzá e példányhoz a budapesti illetőségű, és akkoriban növényi „,csere-egylet”et müködtető Richter Lajostól (vö. BALOGH 2011). Miután a C. intermedia-nak a Budaihegységből egyetlen biztos herbáriumi példánya sem ismert, nagyon valószínű, hogy Richter másutt gyüjtötte, vagy máshonnan szerezte be a növényt, s Márton „Budae” megjegyzése valójában csak Richter székhelyére utal. Nem véletlen, hogy Jávorka ceruzával ráírta a lapra: „vix ad Budam lecta” (aligha Budán szedve). HEGEDÜs (1994: 31) „Corydalis ×fabacea” adatai a Ferenc-hegyről és a Remete-szurdokból föltehetően a $C$. cava (L.) Schweigg. \& Körte és a $C$. solida (L.) Clairv. vélelmezett hibridjére, nem pedig C. intermedia-ra utalnak.

Úgy tűnik, a C. intermedia a Budai-hegységben egy jól körülhatárolható tömbben, főképpen a piliscsabai Hárs-hegy különböző módon átalakított (részben akácosított) 
gyertyános-tölgyeseiben fordul csak elő, e területen viszont igen nagy mennyiségben. Állományai egészen a Kis-Szénás északi lábáig, illetve keletre, a már Pilisszentiván községhatárába tarozó Hárs-erdőig húzódnak. Érdekes, hogy az Európa Diplomás, fokozottan védett területen e faj mindeddig észrevétlen maradt (vö. DoBOLYI et al. 2008).

Corydalis pumila (Host) Rchb. - B: Törökbálint: Hamzsabégi-erdő (Érd-Parkváros mellett) [8579.3], Nagy-erdő [8579.3] (Érd-Parkváros mellett), Szabadházi-hegy [8579.4]. - P: Csobánka: Macska-völgy [8379.4]; Kesztölc: Klastrom-szirtek [8279.3].

Adataink kiegészítések a faj Budapest déli előteréből és a Pilisből ismert előfordulásaihoz (vö. KUN 1996a, BARINA 2009, SOMLYAY 2009).

Dactylorhiza sambucina (L.) Soó - V: Pomáz: Messelia [8380.1] („Pomáz”, Priszter, cit. BoRSOS 1960: 102), „Pomáz, bokorerdőben, a gyümölcsösöknél”, Gotthárd, 1982, GYÖ); Szentendre: Asztal-kő [8380.3] (Degen, 1927, BP), Borz-hegy [8380.3], Kis-Kő-hegy [8380.1] („Kő-hegy”, Lengyel, 1925, BP), Kövecses-hegy [8380.3], Málnás-hegytől D-re (Száraz-patak völgye felett) [8280.3], Nyerges-hegy [8380.3] („Szentendre”, Uherkovich, 1962, JPM), Szmerdán-dúlő és Anna-völgy között [8380.1], Tölgyes-hegy [8379.2].

Hazai adatait BoRsos (1960) foglalja össze. Sajnos a régi irodalmi adatok jó része, csakúgy, mint az újabb keletű gyưjtések némelyike, nem pontosított lelőhelyről származik. Például KERNER $(1877 b)$ „in der Pilisgruppe bei Szt. László zwischen Visegrad und Sct. Andrae” helymegjelölése Pilisszentlászló környékére szúkíthető (Kerner kapcsán BoRsos 1960 mindhárom települést idézi), de ennél pontosabb információt számos herbáriumi példányról (Degen, Lengyel, Trautmann, 1918, BP stb.) sem nyerünk. Azonban kivételek is akadnak („Rózsa-hegy”, Zsák, 1918, CORV, „Málnás-hegy”, Kárpáti Z., 1952, BP). FEICHTINGER (1899: 324) „dömösi” adata valószínúleg a Dobogókőre vonatkozik, ahonnan a Növénytárban (BP) szép bizonyító példányokat találtunk (Thaisz, Filarszky, 1901 stb.).

Daphne cneorum L. - B: Budakeszi: Fekete-hegyek DK-i nyúlványa (Szarvas-ároktól Ny-ra) [8479.3] („,budakeszi kincstári erdőnek a pátyi közalapítványi erdővel határos részén”, SEYMANN 1908; Boros, 1950, BP); Budaörs: Csík-hegytől Ny-ra levő csúcsok [8579.1] („Csiki-hegy”, SEYMAnN, 1908), Ló-hegy [8579.2] (Lengyel, 1921, BP), Szállás-hegy [8579.2]. - P: Piliscsaba: Kis-Kopasz-hegy [8379.3] (Filarszky, 1912, BP), Kis-Széna-hegy [8379.3]; Pilisszentiván: Kakukk-hegy [8379.3] (Bőhm, 2002, BP); Pilisvörösvár: Őr-hegy [8379.3] („Zajnáth-hegyek”, Boros, 1932, BP; naplója szerint az adat az Őr-hegyre vonatkozik), Vörös-hegy [8379.3] (Degen, 1920, BP).

A faj klasszikus előfordulásainak egy részét (Csíki-hegyek: Huszonnégyökrös-hegy, Farkashegy, Szekrényes; Szénás-hegycsoport: Disznófő, Kis-Szénás környéke, Iváni-hegy) az újabb munkák (pl. CsONTOS \& LőKÖS 1992, KÉZDY \& TímÁR 1999, SOMLYAY 2000, DOBOLYI et al. 2008) megerősítették. A fenti saját adataink részben újak, részben mások korábbi - herbáriumi gyűjtéssel dokumentált - lelőhelyeinek megerősítései. Az utóbbi lelőhelyek egy része kimaradt KÉZDY \& TímÁR (1999) áttekintéséből. A budakeszi lokalitással kapcsolatban megjegyezzük, hogy a Szarvas-árokkal (= Hosszútöltés-árok-völgy, Dám-völgy) területi kapcsolatba hozható 1940-es évekbeli gyüjtések (BP) mind a völgy hársbokor-hegyi (K-i) oldalára vonatkoznak.

Echium maculatum L. (Pontechium maculatum (L.) Böhle \& Hilger) - B: Budaörs: Tétényilegelő (Szajkó utca közelében) [8579.4] („Kammerwald”, SADLER 1818). - P: Budakalász: Monalovác-hegy [8380.3].

Budai-hegységi adatait SOMLYAY (2009) tekintette át. A Tétényi-platóról régóta ismert, de a Mechanikai Művek környékén lezajlott (és tervezett) parcellázások (vö. KuN 2010) miatt az itteni populáció végveszélybe került. Budakalász környéki (nem pontosított lelőhelyü) „múltbéli” adatára HAHN (2012) utalt, de a szerző maga nem észlelte a növényt. 
Epipactis futakii Mered'a \& Potůček - P: Esztergom: Cserepes-völgy [8278.4], Fekete-hegy [8279.3]; Pilisszántó: Som-hegy alatti völgy [8379.1], Som-hegytől K-re [8379.1]; Pilisszentkereszt: Hármasforrás-völgy [8279.3], 553 m-es csúcs alatt [8279.3]; Pilisszántó - Pilisszentkereszt: Orosdy-kastély környéke [8379.1], Pilis-oldal [8379.1]. - V: Pilismarót: Hoffmann-vadászház [8279.3], Malom-völgy [8279.1].

Új a Visegrádi-hegység flórájára; itt először a Hoffmann-kunyhó (ma vadászház, fogadó) közelében találták Bérces Sándor és Csáky Péter, a DINPI munkatársai. A faj 2008-ban került elő a Pilisben, mint Magyarországra új adat (SOMLYAY 2010), később megtalálták a Mátrában is (MAGOS et al. 2012).

Epipactis leptochila (Godf.) Godf. - B: Budapest: Budakeszi-erdő (a Csacsi-réttől Ny-ra) [8479.4], Sváb-hegy (az Anna-rét mellett) [8479.4]. - P: Pilisszentkereszt: Hármasforrásvölgy [8279.3], Szurdok [8379.1]. - V: Pilisszentlászló: Szent László-völgy (E. neglecta-val együtt) [8279.4]; Tahitótfalu: Hétvályús-forrás [8280.3]; Visegrád: Apát-kúti-völgy [8279.4].

Új a Budai-hegység és a Visegrádi-hegység flórájára, a Pilisből is csak nemrég ismerjük (SOMlYay 2010, vö. SUlYOK \& MolnÁR 2011b). A Budai-hegységben, mindkét említett helyen, Semperger Zsolt fedezte fel, levélbeli útmutatása alapján mi is megtaláltuk. A visegrádihegységi Epipactis lelőhelyek közül a tahitótfaluira Grósz Róbert, a DINPI munkatársa figyelt fel, az állomány faji azonosítását mi végeztük.

A csőrös nőszőfüt - Vajda László 1953-as vértesi (Oroszlány: Gyertyános) példánya alapján - HoluB (1972) mutatta ki újként a magyar flórára. Sajnos Holub a magyarországi vizsgálatai során nem helyezett revíziós cédulákat az általa látott példányokra. Így a valószínűsíthető Vajda-féle példányt (BP 196796) is csak jóval később, 2010-ben revideálta Molnár V. Attila. A faj sokáig ismeretlen maradt hazánkban. Simon (1992) még csak a régi vértesi adatot citálta, MolnÁR et al. (1995) az ország három pontjáról jelezték, MoLNÁR (2000, 2003) pedig - a Dunazug-hegyvidék kivételével - már számos lelőhelyről közölte.

Epipactis microphylla (Ehrh.) Sw. - B: Budajenő: Fajzási-erdő [8479.1]; Budapest: Budakeszi-erdő - Virág-völgy [8479.4] („In sylvis ad Buda Kezi”, Sadler, s. d., BP, Heuffel, 1826, BP), Diós-árok [8479.4], Harang-völgy [8479.4], Hármashatár-hegy [8480.1], Kecske-hegy [8479.4], Normafa-lejtő [8479.4], Remete-hegy [8480.3], Remete-hegy Mátyás-hegy nyerge [8480.3], Rupp-hegy [8579.2], Szépvölgyi-dűlő [8479.2, 8479.4] („Szép-völgy”, SOMLYAY 2011b), Táboros-hegy [8579.2], Tündér-hegy - Tündérhegyi-út [8479.4] („ad rivulum pone viam quae a Budakezi ad Sauwinkl ducit”, SADLER 1826, BorBÁs 1879), Virágos-nyeregtől ÉK-re (Erdőalja-út) [8479.2]; Nagykovácsi: 429 m-es hegy a Homok-hegytől D-re [8479.1], Cseresznyés-erdő [8479.1], Széna-hegy és Forrásdűlő között [8479.1]; Pilisszentiván: Hosszú-árok [8479.1], Iváni-hegy [8379.3] („sub saxo Egyeskő”, Degen, 1926, BP); Solymár: Kerek-hegy [8479.1]. - P: Csobánka: Hosszúhegy [8379.2], Kerekes-hegy [8379.4], Ziribári-nyereg [8379.2]; Pilisborosjenő: EzüstKevély [8379.4], Magas-erdő [8379.4], Nagy-Kevély [8379.4], Vendel-hegy [8379.4]; Pilisszántó: Pilis [8379.1] (Grundl ?, 1857, SZE, FEICHTINGER 1865), Som-hegy alatti völgy [8379.1], Szántói-nyereg [8379.1]. - V: Esztergom: Vaskapu [8278.2]; Tahitótfalu: Leánykút - Ugró-patak völgye [8280.3].

Budai-hegységi adatait SOMLYAY (2011b) tekintette át, utalva a régi zugligeti adatok pontosításának nehézségére. A Zugliget környékén mi a Harang-völgyben, a Normafa-lejtőn és a Mátyás király - Tündérhegyi út menti erdősáv számos pontján észleltük a fajt. BoRBÁS (1879) és ZsÁK (1916) munkái alapján úgy tűnik, hogy a főváros tágabb környékén terjedőben van. A Visegrádi-hegységben igen ritka (vö. MoLnÁr 2011a). Feichtinger 1858ban gyűjtött példányának (BP) cédulaszövege („Esztergom magasabb hegyi erdőkben”) akár a Pilisre is vonatkozhat, különösen annak tükrében, hogy Esztergom megyei flóraművében (FEICHTINGER 1899: 328) így fogalmaz: „Ritka a szentléleki magasabb hegyi árnyas erdőkben”. 
Epipactis muelleri Godfery - B: Budapest: Csúcs-hegy [8479.2], Hármashatár-hegy [8480.1], Kecske-hegy [8479.4], Látó-hegy [8480.3], Remete-hegy [8480.3], Szép-völgy [8479.4], Szépvölgyi-dúlő [8479.2, 8479.4], Virágos-nyeregtől ÉK-re (Erdőalja-út) [8479.2], Újlakihegy (D-i lába) [8479.4], Zugliget (az „Istenszeme” fölött) [8479.4]. - P: Pilis (D-i lába, Orosdy-kastély mellett, Trézsi-kút) [8379.1] (HoLuB 1972). - V: Tahitótfalu: Ugró-patak völgye [8280.3].

Új a Budai-hegység és a Visegrádi-hegység flórájára, de a Pilisből is csak egyetlen régi irodalmi adatát ismertük eddig. Utóbbi helyről - Degen 1926-ban a Pilis hegyen gyűjtött növénytári példányára hivatkozva - HoluB (1972) közölte, ez akkor a faj első hazai adata is volt egyben. Holub felfedezése a szinopszis ötödik kötetébe (Soó 1973) még nem, csak a hatodikba (Soó 1980) került bele, később Simon (1992) és MoLnÁR $(2000,2009)$ is átvette. MolNÁr et al. (1995) és SULYOK \& MolnáR (2011a: 235) ponttérképén ez az archív adat jelenik meg. Jóllehet az utóbbi években a faj hazánk sok tájegységéből előkerült (vö. SULYOK \& MOLNÁR 2011a), az eredeti pilisi lelőhely mind ez ideig megerősítetlen maradt.

Amint a csőrös nőszőfűnél említettük, Holub nem revideálta az általa megvizsgált magyarországi példányokat. A Növénytár herbáriumában azonban rábukkantunk a Degenféle gyüjtés (1926. július 18.) három lapjára, amelyek cédulaszövege egymással és a HoLUB (1972: 99) által megadott lokalitással egyező (,in monte Pilishegy supra Pilis-SzentKereszt”). Ezek a lapok legalább két Epipactis fajt tartalmaznak. Egyrészt virágzás elején lévő E. helleborine (L.) Crantz-ot (BP 337101 ?, BP 337102), másrészt egy jóval karcsúbb, keskenyebb levelű, elvirágzófélben lévő növényt (BP 337104), amelyet Molnár V. Attila 2010-ben - föltehetően a virágok aránylag hosszú kocsánya miatt - E. voethii Robatsch-ként revideált. Az atlasz Vöth-nőszőfüvet tárgyaló fejezetének ponttérképén (MÉszÁRos et al. 2011: 232) a Pilis hegy e revízió alapján jelenik meg.

Véleményünk szerint azonban a BP 337104 példány nem E. voethii, hanem E. muelleri, és minden bizonnyal ennek alapján publikálta HoLUB (1972) a Müller-nőszőfüvet Magyarországról. Közismert, hogy az orchideák, különösen az apró minőségi bélyegekben különböző nőszőfüvek azonosítása herbáriumi példányok alapján sokszor szinte lehetetlen. Habár a szóban forgó két faj ivaroszlopának struktúrája jelentősen különbözik egymástól, préselt állapotban a térbeli torzulások miatt jószerével csak a portoksapka alakjára hagyatkozhatunk. A Müller-nőszőfü portoksapkája ugyanis madárcsőrszerúen megnyúlt, csúcsán kampósan hegyesedő, míg a Vöth-nőszőfünél (és más rokon fajoknál, ill. az E. helleborine esetében) ilyet nem tapasztalunk. A Müller-nőszőfü portoksapkájának jellegzetes alakját, amelyet már ROBATSCH (1993), a Vöth-nőszőfü leírója is diagnosztikus különbségként emelt ki, az ominózus Degen-féle példányon (BP 337104) - némi preparálás után - sikerült megfigyelnünk. Határozásunkat Sulyok József (Eger - Felsőtárkány) megerősítette.

Epipactis neglecta (Kümpel) Kümpel - P: Esztergom: Cserepes-völgy [8278.4]; Pilisszántó: Som-hegy alatti völgy [8379.1], Som-hegytől K-re [8379.1]; Pilisszentkereszt: Mogyorósárok [8379.1], Szurdok [8379.1]. - V: Dömös: Piroska-hegy [8279.1]; Leányfalu: Csabakút [8280.3], Sztaravoda-völgy [8280.3]; Pilismarót: Malom-völgy [8279.1, 8279.3]; Pilisszentlászló: Szent László-völgy [8279.4]; Szentendre: Kis-kő-hegy és Cseresznyehegy közötti völgy [8380.1]; Visegrád: Apát-kúti-völgy [8279.2, 8279.4], Kis-Disznó-hegy és Görbe-hajtás között [8279.4], Nagy-erdő [8279.2].

Új a Pilis és a Visegrádi-hegység flórájára (vö. SULYOK et al. 2011), bár valószínűleg egyik hegységben sem túlságosan ritka. Számos olyan példányt találtunk ugyanis, amelyik igen nagy valószínűséggel e fajhoz tartozik, de nyíló virág hiányában biztos azonosítását későbbre halasztottuk. 
Epipactis peitzii H. Neumann \& Wucherpfennig - B: Budapest: Vihar-hegy [8479.2]; Nagykovácsi: Cseresznyés-erdő [8479.1]; Telki: Vasvári-erdő [8479.1]. - P: Pilisszántó: Pilis-oldal [8379.1], Som-hegy alatti völgy [8379.1], Som-hegytől K-re [8379.1]; Pilisszentkereszt: Mogyorós-árok [8379.2].

Új Magyarország flórájára. Az ismeretlen fajra Csábi Miklós figyelt föl először Nagykovácsi mellett 2006-ban, majd a lelőhelyet együtt is felkerestük. Faji azonosítására csak 2011-ben került sor - Molnár V. Attila (Debrecen) közbenjárására - Wolfgang Wucherpfennig (Eching) segítségével, aki a fajt Németországból (Hohlenfels) 1996-ban leírta. A magyarországi izolált előfordulás azóta egy német honlapon (http://www.aho-bayern.de/epipactis/ep_peit.html) is fel van tüntetve.

Bár a növény a többi ismert hazai rokonfajtól egyértelműen különbözik, megítélésünk szerint az E. peitzii és általában az E. leptochila alakkörébe tartozó viscidium nélküli Kárpátmedencei taxonok rokonsági viszonyainak, faji tagolódásának és elterjedésének tisztázása további vizsgálatokat igényel. A gyors terepi azonosítást és a további kutatást elősegítendő, az alábbiakban röviden jellemezzük az E. peitzii diagnosztikai bélyegeit a legközelebbi hazai rokon fajoktól. Az E. leptochila csoport fajait általánosan jellemzi, hogy a murvalevelek (főleg az alsók) rendszerint hosszúak, a lomblevelek \pm a szár két átellenes oldalán (legalábbis nem kifejezetten spirálisan) állnak, tövük sárgás színű, az erős szár töve pedig határozottan lilás futtatású (bár utóbbi bélyeg tekintetében éppen az E. peitzii kivétel). Közös bélyegük a hegyes epichil is.

Az E. peitzii virága bókoló, kevéssé nyílik ki, halvány színű, mondhatni a legkevésbé „színes” a csoporton belül. A külső lepellevelek zöldesek, a belsők, illetve a mézajak zöldesfehérek, viszont az epichildudorok környéke fehérlő vagy néha rózsás. A hegyes epichil csak a frissen kinyílt virágoknál mereven előreálló, a virágzás folyamán hátrahajlik. A mesochil \pm szűk, U-alakú. Ivaroszlopára jellemző, hogy a viscidium mindig hiányzik, a klinandrium nagyon rövid vagy hiányzik, a pollíniumok szinte a bibefelületen ülnek.

Az E. leptochila csoport hazai fajai közül az E. futakii virága nem nyílik ki, és a zárva maradó lepellevelek töve jellegzetesen barnásibolyás színű. Az E. leptochila virága ellenben még az E. peitzii-nél is jobban kinyílik, az epichil a virágzás során mereven előreálló marad, az epichildudorok környéke rózsás-ibolyás színű. Az aránylag széles mesochil-ja V-alakú, ivaroszlopán a viscidium hamar funkcióképtelenné válik, néha hiányzik, a klinandriuma fejlettebb. Az E. neglecta virága szélesre nyílik, többnyire színes (rózsás, lilás), az epichil a virágzás során erőteljesen hátrahajlik. A mesochil-ja U-alakú, nagyon szűk, a legszűkebb a többi fajhoz képest. E faj ivaroszlop-struktúrája az E. leptochila-éra hasonlít.

Az E. peitzii (javasolt magyar név: Peitz-nőszőfű) virágzási ideje Magyarországon június vége - július, az egyes virágok nagyon rövid ideig nyílnak.

Epipactis purpurata Sm. - B: Nagykovácsi: Cseresznyés-erdő [8479.1]. - P: Esztergom: Cserepes-völgy [8278.4], Fekete-hegy, Pilis-nyeregtől ÉNy-ra (lus. chlorophylla is) [8279.3]; Pilisszántó: Hosszú-hegy [8379.1], Som-hegy alatti völgy [8379.1]; Pilisszentkereszt: Hármasforrás-völgy (lus. rosea is), Kakas-hegy [8279.3], Ördög-lyuk és az 553 m-es névtelen csúcs között [8279.3]. - V: Pilismarót: Bitóci-völgy [8279.1], Fűrésztisztás közelében [8279.3], Hoffmann-vadászház környéke [8279.3], Kis-Disznó-hegy [8279.1], Malom-völgy [8279.1], Malom-völgyi-árok [8279.3], Német gyerek halála [8279.3], Schullerok [8279.3]; Visegrád: Keserűs-hegy [8279.4].

A Budai-hegységből MolnÁR $(2000,2003)$ jelzi először, de konkrétabb lelőhelyet (a Szénáshegycsoport egy pontjáról) eddig csak egyetlen alkalommal közöltek (Halász Antal in DoBOLYI et al. 2008). A nagykovácsi adatunk közeléből (Széltörés-erdő Nagykovácsi és Telki határán) már régebben ismert a faj előfordulása, a Telki határába tartozó Vasvári-erdőből e kötetben CSÁBI \& HALÁSZ (2016) közlik. A Pilisből és a Visegrádi-hegységből is csak néhány korábbi adata ismert. 
Epipactis tallosii Molnár et Robatsch - B: Budapest: Felsőrákosi-rétek [8581.1]. - P: Esztergom: Cserepes-völgy [8278.4], Pilisszántó: Zuhamenyica [8379.1]. - V: Dömös: Makó-réti-forrás közelében [8279.3].

Új a Pilis hegység flórájára. Budapest környékéről kevés adata ismert (vö. VIDÉKI, SULYOK \& MoLNÁR 2011). A régi herbáriumi lapok közül valószínűleg e fajt reprezentálják Tauscher Gyula Csepel-szigeti „Epipactis latifolia” példánya (1869, BP), valamint Hermann Gábor - E. microphylla és E. rubiginosa néven cédulázott - gyưjtései (1883, 1884, BP) a Pesti-sík ferencvárosi részéről (revideálta Molnár V. Attila). Ennek megfelelően HERMANN (1885) ferencvárosi „E. microphylla” és „E. rubiginosa” irodalmi adatai E. tallosii-ra értendők.

$\mathrm{Az}$ általunk megfigyelt egyes budapesti példányok a morva nőszőfüre ( $E$. moravica Batoušek) emlékeztetnek, a két faj taxonómiai viszonyának, ill. hazai elterjedésének tisztázása további vizsgálatokat igényel.

Gagea bohemica (Zauschn.) Schult. et Schult. - B: Budakeszi: Kecske-hegy [8579.1]; Budaörs: Odvas-hegy [8579.2]; Budapest: Tétényi-legelő (a víztorony közelében) [8579.4] (Entz, 1866, BP); Nagykovácsi: Vörös-pocsolyás-hát [8479.1].

A fóváros környékén (Kamaraerdő) Entz Géza fedezte fel 1866-ban (ENTZ 1868), majd 1873ban Simonkai ugyanitt és a Vadaskerti-hegyen (Állatkert-hegy) is gyüjtötte (BP, vö. SIMONKAI 1876). KuN (1994) a vörös-kővári populáció felfedezésekor föltehetően elnézte az utóbbi adatot, pedig az általa hivatkozott munka (BoRBÁs 1879) szintén említi az Állatkert-hegyet, azaz a mai Nyéki-hegy - Vadaskerti-hegy környékét. A budaörsi Odvas-hegyen Rédei Tamás (ÖBI) fedezte föl, s mutatta meg a lelőhelyet. A területünkön meglehetősen ritka faj (KUN 1994, SOMLYAY 2011b), jobbára néhány egyedből álló állományokkal. Erősebb populációja csak olyan helyen maradhatott fenn, ahol megfelelő (savanyú) az alapkőzet, és a szerencsés környezeti adottságoknak (viszonylagos izoláltság, vagy a folyamatos emberi tevékenység vadriasztó hatása) köszönhetően viszonylag kis mértékű a vadterhelés. A fentiek közül ilyen a Kecske-hegy Ény-DK-i gerincén lévő kisavanyodott talajú sziklakibúvás.

Gymnadenia conopsea (L.) R. Br. - B: Budapest: Diós-árok [8479.4] („Schwabenberg”, Bohatsch, 1877, BP), Normafa-lejtő alja [8479.4] (Entz, 1865, BP); Nagykovácsi: Cseresznyés-erdő szegélye [8479.1]. - P: Csobánka: pilisszentkereszti Szurdok D-i végénél lévő kőbánya [8379.2]; Esztergom: Nagy-Strázsa-hegy [8278.4] („e pratis montanis ad Dorog”, Grundl, s. d., SZE). - V: Pilisszentlászló: Ispán-rét [8279.4] („ÖregVágás-hegy”, Horánszky, 1954, BP); Szentendre: Szmerdán-dűlő - Kis-Kő-hegy [8380.1] („in valle Sztaravoda”, Andrasovszky, 1916, BP).

BoRBÁs (1879) a Pesti-síkon kívül a „budai magasabb hegyek”-ről közli. Régi, herbáriumi példánnyal igazolt lelőhelyeinek többsége azonban már a múlté; eddig egyedül a Normafalejtőről származó adatát sikerült megerősítenünk. A szűkebb értelemben vett Pilisből csak egy-két 19. századi herbáriumi példánya ismert, a Strázsa-hegyről BAUER $(1996,2001)$ nem jelzi. Új adataink közül kiemeljük a szentendrei lelőhely százas nagyságrendű populációját.

Gymnadenia odoratissima (L.) Rich - B: Budapest: Ördög-orom [8579.2] (Zsák, 1916, CORV).

A kevés és régi budai-hegységi előfordulásból ma csak ezt az egyet tudjuk megerősíteni. Az irodalmi adatok (pl. KERNER 1877b, BORBÁs 1879) és gyűjtések zöme is a szűkebb környékről (Farkas-völgy, Farkasrét, Sas-hegy) származik.

Himantoglossum jankae Somlyay, Kreutz et Óvári - P: Csobánka: Hosszú-hegy (475 m-es csúcs környéke) [8379.2]; Pilisszántó: 386 m-es hegy [8379.1], Som-hegy [8379.1].

A faj hazai adatait SULYOK et al. (1998) foglalják össze ( $H$. caprinum név alatt). A Pilisben legrégebben a Pilis hegy Piliscsév felé néző oldaláról ismert Uávorka, 1903, BP, vö. JÁvORKA 1904), ahol ma is él. A szentkereszti Szurdok melletti gerincről Németh Ferenc (in PRISZTER 
1985) közölte, ez a lokalitás föltehetően azonos Kováts Ferenc („Pilisszentkereszt”, 1926, SZIE) gyűjtésével. A közeli Hosszú-hegy pilisszántói határában Bőhm Éva bukkant rá 1994ben (vö. SULYOK et al. 1998). A most közölt adataink kiegészítések a környékbeli ismert előfordulásokhoz.

Lathyrus sphaericus Retz. - B: Budapest: Fekete-fej [8479.4] (Kárpáti Z., 1948, BP), FelsőPatak-hegy [8479.2], Ördög-orom [8579.2] (HEGEDÜs 1994); Nagykovácsi: Hosszú-Erdőhegy [8479.2] („Remete-hegy”, Csapody V., 1933, BP), Kecske-hát [8479.3, 8479.4]. - P: Csobánka: Csúcs-hegy [8379.4], Kis-Kevély [8379.4] („Kevély-nyereg”, Kárpáti Z., 1948, BP); Pilisborosjenő: Nagy-Kevély [8379.4] (Boros, Vajda, Kárpáti Z., 1940, BP); Pilisszántó: Pilis (a hegy déli részén több ponton) [8379.1] (Boros, Lengyel, Kováts, Pénzes, Zsák, 1932, BP), Som-hegy [8379.1]; Pilisszántó - Csobánka: Hosszú-hegy [8379.1, 8379.2] („Csobánka: Hosszú-hegy, a barlangtól K-re”, Barina \& Pifkó, 2002, BP). - V: Pilisszentlászló: Tüskés-hegy (Tövises-hegy) [8279.4]; Visegrád: Dobos-hegy [8279.2], Öreg-Pap-hegy [8279.4] („inter Visegrád et Pilis-Szt-László”, Simonkai, 1871, BP).

A Budai-hegység keleti felében régebben számos helyen gyűjtötték, ezen adatok zöme manapság megerősítetlen. A Pilisben szintén a hegység keleti, ill. délkeleti felében a leggyakoribb, sőt, kedvező években tömeges is lehet (pl. a Hosszú-hegy teljes vonulatán). BŐHM \& FACSAR (1999) a Pilis hegyről nem jelzik. A pilisszentlászlói adat érdekessége, hogy az újabb adatoktól (vö. BP, BÁNKUTI 2000, BARINA \& PIFKó 2007) eltérően ez a Visegrádi-hegység belső részéről származik.

Limodorum abortivum (L.) Sw. - B: Budajenő: 471 m-es csúcs környéke [8479.1], Cseresznyés-völgy É-i pereme [8479.1]; Budakeszi: Sorrento-tól É-ra [8579.2], Szarvasároktól Ny-ra (több ponton) [8479.3] („Erti-től északkeletre eső erdőben”, Rosemberszky, 1958, BP); Budaörs: Csík-hegy [8579.2] („prope Budaörs, Sándor, s. d., BP), Huszonnégyökrös-hegy [8579.1], Nap-hegy [8579.2]; Budapest: Csúcs-hegy [8479.2], Farkas-völgy [8579.2] (Polgár, 1898, DE, vö. Soó \& BoRSos 1966: 325), Ferenc-halom [8479.4] (Felföldy, 2000, BP), Hármashatár-hegy [8479.2], Kecske-hegy [8479.4] (Pénzes, 1958, BP), Ördög-orom [8579.2] (Vajda, 1938, BP), Rupp-hegy [8579.2] (HEGEDÜs 1994), Táboros-hegy [8579.2], Tündér-hegy [8479.4] („unter dem Joannisberg”, SADLER 1818), Vaskapu-hegy (Apáthy-szikla) [8479.4], Vihar-hegy [8479.2]; Páty: Fekete-hegyek (több ponton) [8479.3] Uávorka, 1936, BP); Perbál: Szerdahelyi-vágástól Ny-ra [8478.2], Szerdahelyi-vágás fölött [8478.2, 8479.1]; Pilisszentiván: Kis-Szénás ÉK-i nyúlványa [8379.3] (Kárpáti Z., 1952, BP, CORV). - P: Csobánka: Hosszú-hegy [8379.2], Kerekeshegy [8379.4], Kis-Kevély [8379.4], Oszoly [8379.4]; Pilisborosjenő: Ezüst-Kevély [8379.4], Magas-erdő [8379.4], Nagy-Kevély [8379.4] (Toborffy, 1969, SZIE); Pilisszántó: Hosszú-hegy [8379.1], Szántói-nyereg [8379.1]; Pilisszántó - Pilisszentkereszt: Pilis [8379.1] (Bartha, 1928, BP; Boros, 1946, BP). - V: Leányfalu: Berseg-hegy [8280.3]; Pilisszentkereszt: Fagyos katona [8279.3], Kakas-hegy [8279.3].

Habár e faj a Dunazug-hegyvidéken elég sokfelé előfordul (MoLNÁR \& ILLYÉs 2011: 267), a konkrét irodalmi adatok száma aránylag csekély (pl. Soó \& BoRSos 1966, HEGEDÜs 1994, KuN 1996a, BAUER 2001, SOMLYAy \& PifKó 2002, Dobolyi 2004, BARINA \& PifKó 2007, Dobolyi et al. 2008). Az új lelőhelyeink közül kiemeljük a táboros-hegyi és a vihar-hegyi százas nagyságrendű populációkat.

Muscari tenuiflorum Tausch - B: Budajenő: a 471 m-es csúcs környéke [8479.1]; Budapest: Vihar-hegy [8479.2]. - P: Csobánka: Kis-Kevély [8379.4]; Pilisszentkereszt: Pilis-hegy alatti földek (a Golyvás-forrás közelében) [8379.1] („Pilis”, Vajda, 1940, BP).

Hiányosan ismert faj kevés biztos adattal, amelynek oka az igen hasonló, de sokkal gyakoribb üstökös gyöngyikével ( $M$. comosum (L.) Mill.) való gyakori összetévesztése (vö. SomLYAY $2011 b)$. 
Neotinea tridentata (Scop.) R.M. Bateman, Pridgeon \& M.W.Chase - B: Biatorbágy - Érd Sóskút - Törökbálint: Hamzsabégi-erdőtől Ny-ra [8579.3]; Budakeszi: Fekete-hegyek (DK-i rész, számos ponton) [8479.3] („Hosszú-árok-völgy”, Boros, 1950, BP), Kakukkhegy [8479.3], Nagyszénászug [8579.2]; Budapest: Csillebérc [8579.2] (Priszter, 1938, BPU), Kecske-hegy [8479.4] (Czakó, 1888, DE), Kis-Hárs-hegy [8479.4] („in monte Tiliarum", Simonkai, 1871, BP, Felföldy, 2000, BP), Újlaki-hegy [8479.2] (Hegedüs, 1976, BP); Nagykovácsi: Cseresznyés-erdő [8479.1], Homok-hegy [8479.1] (Pifkó, 2005, BP), Homok-hegytől D-re (429 m-es csúcs) [8479.1] (Pifkó, 2003, BP), Széna-hegy [8479.1]; Páty: Fekete-hegyek (Tarnai-pihenő környéke) [8479.3] („Nagykopaszhegy”, Boros, 1916, BP); Perbál: 471 m-es csúcs környéke [8479.1] („Nagykovácsi felett Perbál felé koronauradalmi erdő", Jávorka \& Zólyomi, 1937, BP), 411 m-es csúcs környéke [8478.2], 412 m-es csúcs környéke (Szerdahelyi-vágástól Ny-ra) [8478.2], Meszes-hegy [8478.2], Szerdahelyi-vágás fölött [8478.2, 8479.1]; Törökbálint: Tétényi-legelő (Mechanikai Művektől É-ra) [8579.4] („,in silva Kamerali”, Simkovics, 1871, BP). - P: Esztergom: Kishegy [8278.4] („Kétágú-hegy”, Grundl, 1837, SZE, sub O. ustulata (rev. Molnár V. Attila)), Nagy-Strázsa-hegytől É-ra lévő domb [8278.2], Nyárasd és Öreg-szállás között [8278.4], sátorkőpusztai homokbánya [8278.4]. - V: Dunabogdány: Csepri-hegy (Sajgó) [8280.1]; Pilisszentlászló: Öreg-Pap-hegy lába [8279.4]; Szentendre: Asztal-kő [8280.3], Nyergeshegy [8280.3] („montes inter Leányfalu et Szentendre”, Degen, 1927, SZIE); Visegrád: Dobos-hegy [8279.2], Fekete-hegy [8279.2] („visegrádi hegyeken”, BORBÁs 1875, „Visegrád”, Priszter, 1941, BPU).

Budapesten, ill. közvetlen környékén HEGEDÜs (1994) az Ördög-oromról, az Újlaki-hegyről és a Hármashatár-hegyről, KeCSKÉs (1994) és KECSKÉS \& KUN (2004) a Tétényi-fennsíkról, SOMLYAY (2000) a Zugligetből (Hunyadi-orom) és a Ferenc-halomról, Szollét (2007) a Harang-völgyből, TóTH \& PAPP (2012) a Sas-hegyről erősítették meg régi adatait. Új adataink közül kiemeljük az Érd ÉNy-i végénél talált, százas nagyságrendű, négy település közigazgatási határába tartozó populációt. A budakeszi, nagykovácsi és perbáli lelőhelyeink szervesen kapcsolódnak a Kutya-hegytől Ny-ra lévő jól ismert (vö. CsonTos \& LőKös 1992, DовоLYI et al. 2008) állományokhoz. A pilisi Strázsa-hegy környékén BAUER $(1996,2001)$ és BAUER \& BARNA (1999) csak a Tábla-hegyről jelzik, a sátorkőpusztai homokbányából pedig ismeretlen volt (vö. BARINA 2001). A Visegrádi-hegységben a faj pilisszentlászlói adata az első, amelyik a hegység belső területéről származik (vö. BARINA \& PIFKó 2007).

Neotinea ustulata (L.) R.M. Bateman, Pridgeon \& M.W.Chase - B: Budakeszi: Fekete-hegyek (DK-i rész) [8479.3], Kakukk-hegy [8479.3], Nagyszénászug [8579.2]; Budaörs Budapest - Törökbálint: Tétényi-legelő [8579.4] („Kamaraerdő alatt”, BorBÁs 1875, „Tétényer Heide”, Bohatsch, 1878, BP, vö. BORBÁs 1879); Budapest: Remete-hegy [8480.3], Tábor-hegy [8480.3] (Boros, 1944, BP); Nagykovácsi: Homok-hegy [8479.1] („Nagykopasz, supra vicum Nagykovácsi”, Papp, 1947, BP, Pifkó, 2005, BP), Kutya-hegy [8479.1] („Koronauradalmi erdő”, Jávorka, 1941, BP, CsonTOS \& LőKÖS 1992), Széna-hegy [8479.1]; Perbál: 471 m-es csúcs környéke [8479.1], 411 m-es csúcs környéke [8478.2], Meszes-hegy [8478.2]; Solymár: Szél-hegy [8379.4]. - P: Esztergom: Csurgó-hegy [8278.4], Kis-Strázsa-hegy [8278.3] [8278.1], Lencse-völgy [8278.4], Nagy-Strázsa-hegy [8278.4], Nagy-Strázsa-hegytől É-ra fekvő dombok [8278.2][8278.4], Nyárasd és Öregszállás között [8278.4], Tábla-hegy [8278.4].

A Budai-hegységből számos korábbi gyűjtése ismert, mára az ismert lelőhelyek száma erősen megcsappant, HEGEDÜs (1994: 65) a fóváros területén nem is találta. A solymári Szél-hegyen a faj több száz töves populációja él, tudomásunk szerint ez a legnagyobb a Budai-hegységben. Jelentős, régóta ismert állományai élnek a Tétényi-fennsíkon, Kamaraerdő mellett („Tétényilegelő"), Budapest, Budaörs és Törökbálint közigazgatási határában egyaránt. [SoMLYAY (2011b) az Orchis coriophora L.-val együtt az O. ustulata-t is felsorolta, de a konkrét lokalitást 
tévesen Törökbálinthoz sorolta]. A pilisi Strázsa-hegy környéki adataink kiegészítések, ill. pontosítások BAUER $(1996,2001)$ és BAUER \& BARNA (1999) dolgozataihoz, akik elsőként hangsúlyozták a faj lokális gyakoriságát.

Neotinea $\times$ dietrichiana (Bogenh.) H.Kretzschmar, Eccarius \& H.Dietr. (= N. tridentata $\times N$. ustulata) - B: Budakeszi: Kakukk-hegy [8479.3], Nagyszénászug [8579.2]; Nagykovácsi: Kutya-hegy [8479.1]; Perbál: Meszes-hegy [8478.2].

Magyarországon igen ritka hibrid, a Budai-hegységben korábban a Hármashatár-hegy tömbjéről és a Sváb-hegyről jelezték (Degen, Trautmann, Zsák, 1920, BP, CORV, vö. Soó 1928: 142, ZSÁK 1941, BORSOS 1962: 61). Mindenütt a szülők társaságában vagy közelében találtuk.

Ononis pusilla L. - B: Budaörs: Farkas-hegy [8579.2], Odvas-hegy [8579.2], Tűzkő-hegy [8579.2]; Budapest: Kis-Hárs-hegy [8479.4] („Hárs-hegy”, Simkovics, 1873, BP), Rupphegy [8579.2] (Degen, Boros, 1918, BP), Táboros-hegy [8579.2] („Farkasrét”, Degen, 1913, BP); Diósd: Kőbánya [8579.4]; Nagykovácsi: Felső-Zsíros-hegy [8479.1], Nagy-Szénás [8479.1] (Kárpáti Z., 1932, BP). - P: Budapest (Békásmegyer): Péter-hegy [8480.1] („Békásmegyer”, Perlaky, 1891, BP, Kárpáti Z., 1949, BP), Puszta-domb [8380.3].

A budaörsi Csíki-hegyekből régóta ismert („Csíki hegy”, Szépligeti, 1884, BP, stb.), de a konkrét lelőhelyek száma kevés (Huszonnégyökrös-hegy: Andreánszky, 1934, BP; Sorrento: Boros, 1944, BP; Út-hegy: Kárpáti Z., 1944, BP). DoвоLYI et al. (1999) nem jelzik.

Ophrys apifera Huds. - P: Esztergom: Kis-Strázsa-hegy [8278.1, 8278.3], Nagy-Strázsa-hegy [8278.4], Nagy-Strázsa-hegytől É-ra lévő mélyedés és domb [8278.4], Nagy-Strázsahegytől DNy-ra lévő domb [8278.3, 8278.4], Tábla-hegy [8278.4]; Pilisszántó: 386 m-es névtelen domb [8379.1]; Pilisszentkereszt: Pilis-hegy alatti földek (több ponton) [8379.1] (RAKSÁNYI 1999). - V: Esztergom: Cigány-kúttól ÉK-re [8278.2], Kusztusi-dűlő [8278.2].

A Pilisben RAKSÁNYI (1999) fedezte fel (vö. MolnáR 2000), föltehetően ezt az adatot vette át BőHM \& FACSAR (1999). Esztergom környékéről BAUER $(1996,2001)$, BAUER \& BARNA (1999) és BARINA (2001) nem jelzik a fajt. Mi a Strázsa-hegy környékén több száz virágzó tövet számoltunk össze, egy helyen szinte kompakt Inula germanica L. állományban (!) találtuk, és előfordult a "var. friburgensis"-nek nevezett változat is. A Pilis-hegy alatti földeken kis egyedszámban észleltük a RAKSÁNYI (1999) által felfedezett helyen, ettől ÉNy-ra azonban százas nagyságrendű, odébb, a Golyvás-forrás közelében pedig újabb kisebb állománya került elő. A Visegrádi-hegység területéről eddig nem volt ismert, a Cigány-kút környéki lelőhelyre Molnár V. Attila hívta fel a figyelmünket. Hazánkban minden bizonnyal terjedőben lévő faj (vö. ÓvÁRI \& MOLNÁR 2011).

Ophrys holubyana Andras. - V: Esztergom: Vaskapu [8278.2].

Új adat a Visegrádi-hegység flórájára, és az egész országban nagy ritkaság (MoLNÁR \& GULYÁS 2005). A faj egyetlen virágzó példányára egy, a DINPI által „Ophrys sp.” előfordulásként jelzett lokalitás ellenőrzése során bukkantunk. Közelében egy elvirágzott $O$. sphegodes Miller példányt, számos bangó tőlevelet és más orchideákat találtunk. A pókbangó nem új a területen, Gotthárd Dénes gyüjtötte (GYÖ) 1977-ben „Vaskapuhegy É-i töve” helymegjelöléssel, amely akár azonos is lehet a mi lelőhelyünkkel.

Orchis mascula L. ssp. signifera (Vest) Soó (O. signifera Vest) - V: Dunabogdány: Köröshegy [8280.1], Kutya-hegy [8280.1]; Leányfalu: Berseg [8280.3], Nyerges-hegy (É-i csúcs) [8280.3]; Pilisszentlászló: Öreg-Pap-hegy [8279.4], Sárkány-oldal [8279.4], Szent Lászlóhegy [8279.4] („Szarvas Szérû”, Degen, 1918, BP, Jávorka 1928, BP); Pomáz: Messelia [8380.1]; Szentendre: Cseresznye-hegy [8380.1] („Pomáz Kő-hegy, Vasas-szakadék feletti erdőben”, Gotthárd, 1977, GYÖ), Kis-Kő-hegy [8380.1] („Kő-hegy”, Thaisz, 1904, BP), Kövecses-hegy [8280.3], Málnás-hegytől D-re (Száraz-patak völgye felett) [8280.3], Nyerges-hegy (Asztal-kőtől É-ra) [8280.3], Szmerdán-dűlő [8380.1], Tölgyes-hegy 
[8280.3]; Tahitótfalu: Hegyesd [8280.1], Öreg-bükk-tető [8280.3], Vörös-kő [8280.3] (Moldvai 1957, SAU, Gotthárd, s. d., GYÖ, vö. BÁNKUTI 2000); Visegrád: Apátkúti-völgy (Somos-bérc és a Süllyedék fölött) [8279.2], Ágas-hegy [8279.4], Gyula-forrás közelében [8279.2], Kis-lapos [8279.2], Nagy-Kilián [8279.2], Nagy-Som-hegy [8279.4], Nyalka-bérc [8279.2], Szarvas-bérc [8279.4], Szarvas-lyuk [8279.4].

A Visegrádi-hegységből elég sok herbáriumi és irodalmi (vö. BoRsos 1963, BARINA \& PIFKó 2007) adata ismert, a régiek sajnos gyakran pontatlan lelőhelyekkel. Állományait a legtöbb helyen erősen vadjárta hegygerincen találtuk, sok tő le volt legelve.

Orchis militaris L. - B: Nagykovácsi: Nagy-Szénás [8479.1] (Boros, 1945, BP, Csontos \& LőKÖs 1992); Perbál: 471 m-es csúcs környéke [8478.2] („koronauradalmi erdő Perbál felé”, Jávorka \& Zólyomi, 1937, BP); Solymár: Alsó-Patak-hegy [8479.2]. - P: Esztergom: Csurgó-hegy [8278.4], Kis-Strázsa-hegy [8278.1], Nagy-Strázsa-hegy [8278.4], NagyStrázsa-hegytől É-ra fekvő domb [8278.2], Tábla-hegy [8278.4]; Pilisszentkereszt: Pilishegy alatti földek (több ponton) [8379.1] („Pilis Szt. Kereszt”, Simkovics, 1871, BP). - V: Esztergom: Vaskapu [8278.2]; Pomáz: Messelia [8380.1]; Visegrád: Disznó-zug [8279.2], Dobos-hegy [8279.2] („visegrádi hegyeken”, BoRBÁs 1875).

A Dunazug-hegyvidéken erősen megritkult faj, állományai főként az Alfölddel határos helyeken maradtak fenn. A pilisi Strázsa-hegy környéki adataink kiegészítések, ill. pontosítások BAUER $(1996,2001)$ dolgozataihoz, aki elsőként hangsúlyozza a faj lokális gyakoriságát.

Orchis pallens L. - P: Csobánka: Derek [8379.2] („bei Csobánka”, KeRner 1877a), Hosszúhegy [8379.2]; Esztergom: Túzköves-árok felett [8278.4]; Pilisszántó: 386 m-es domb [8379.1], Hosszú-hegy [8379.2] (Gotthárd, 1980, GYÖ, vö. BÁNKUTI 2000), Som-hegy [8379.1]; Pomáz: Oszoly [8379.2] (Vajda, 1941, BP). - V: Dömös: Vadálló-kövek [8279.3] (Feichtinger, 1860, SZE, FEICHTINGER 1865); Dunabogdány: Kutya-hegy [8280.1], Len-hegy [8280.1]; Leányfalu: Nyerges-hegy [8280.3]; Pilisszentlászló: Sárkány-oldal [8279.4] (Carex brevicollis DC. és 0 . mascula ssp. signifera társaságában); Pomáz: Kis- és NagyCsikóvár közti nyereg [8379.2] („Kis-Csikóvár”, Gotthárd, 1975, GYÖ, vö. BÁNKUTI 2000); Szentendre: Cseresznye-hegy [8380.1], Kis-Kő-hegy [8380.1] („Kőhegy”, Priszter, ?, cit. BoRsos 1963: 80); Tahitótfalu: Öreg-bükk-tető [8280.3]; Visegrád: Ágas-hegy [8279.4], Görbe-hajtás [8279.4], Szarvas-bérc [8279.4].

Területünkön klasszikus lelőhelye a Pilis hegy (vö. BoRsos 1963), amelynek számos pontján ma is megtalálható. Régi szórványadatait ismerjük a Visegrádi-hegységből, újabban BARINA \& PIFKó (2007) az esztergomi Vaskapuról és a tahitótfalui Kenézakla-tetőről közlik.

Ornithogalum comosum L. - B: Budaörs: Ló-hegy és Csík-hegy közti nyereg [8579.2], Csíkhegy [8579.2] („Csikihegy”, Perlaky, 1893, BP), Prékókörnyék [8579.1], Sorrento [8579.2] (Kárpáti Z., 1943, BP), Szekrényes [8579.2] (Gotthárd, 1984, GYÖ), Tétényi-legelő [8579.4] („Kammerwald”, Richter, 1874, BP); Budapest: Felső-Kecske-hegy [8480.1] („Felső-Kecske-hegy”, Bohatsch, 1878, BP, de ez bizonyára a mai Alsó-Kecske-hegyre vonatkozik), Hármashatár-hegy [8479.2] (Szépligeti, 1884, DE), Látó-hegy [8479.4, 8480.3], Mátyás-hegy [8480.3] (Simkovics, 1873, BP), Nagytétény [8579.4] („Nagytétény”, Lyka, 1906, SZIE), Tábor-hegy [8480.3], Tétényi-legelő [8579.4]; Érd - Sóskút: Erdő-hátdűlő [8579.3], Nagy-mező [8579.3] („Kutyavár”, Degen, Jávorka, 1918, BP); Törökbálint: Nagy-puszta [8579.4]. - P: Budakalász: Monalovác-hegy [8380.3].

A fentiek kiegészítések, ill. pontosítások a korábbi adatokhoz (vö. SomlYAY 2009, 2011b), néhány megerősítéssel. Habár a Tétényi-fennsík Budapest környéki részéről ismerünk régi és pontatlan helymeghatározású példányokat, miután KeCSKÉs (1994) és KeCSKÉs \& KUN (2004) nem jelzik, fontosnak tartottuk a faj itteni, három közigazgatási határhoz tartozó előfordulásainak megerősítését. 
Ornithogalum refractum Kit. ex Schltdl. - B: Biatorbágy (belterület) [8578.2]; Budakeszi: belterület (a temető közelében) [8979.4], Vörös-hegy [8979.4]; Budapest: Sas-hegy [8580.1], Zugliget [8979.4]. - P: Pilisvörösvár (belterület) [8379.3].

A fentiek kiegészítések SomLYAY (2011b) adataihoz, amelyek közül viszont a kispesti (BP 656421) és legalább részben az Orbán-hegyi (BP 656428) adat a magyar növényhatározókból hiányzó 0 . divergens Bor. fajra vonatkozik (rev. Milica Rat, Novi Sad, 2013).

Serratula radiata (W. \& K.) Bieb. - B: Budapest: János-hegy [8479.4] (Máthé, 1947, BP 718046), Normafa-lejtő [8479.4]; Perbál: Meszes-hegy [8478.2], Zajnát [8378.4].

A fentiek kiegészítések SOMlyay $(2009,2011 b)$ dolgozataihoz. Szollát (2007) a Harangvölgyből jelezte a faj előfordulását, ez az adat SomLYAY (2009) áttekintésből kimaradt. A Normafa-lejtő több pontján előfordul, az egyiket Csáky Péter (DINPI) mutatta meg. A meglepő, János-hegyi egykori előfordulást Máthé Imre példánya igazolja, megerősítésre vár. Érd környékéről számos korábbi adata ismert (vö. KuN 1994, 1996a, SoMLYAY 2009), újabban SZERÉNYI (2014) az érdi Fundoklia-völgyben és a Dobogón is megtalálta.

Silene viridiflora L. - B: Nagykovácsi: Vörös-pocsolyás-hát (a Vörös-pocsolyától ÉK-re) [8479.1]; Perbál: 361 m-es hegy környéke [8478.2]. - P: Csobánka: Macska-völgy [8379.4], Ziribári-nyereg [8379.2]; Csobánka - Pilisszántó: Hosszú-hegy [8379.1]; Pilisszántó: Pilis (DNy-i oldal, több ponton) [8379.1] (JÁVORKA 1904).

Ez, a Visegrádi-hegységben elterjedt faj (BARINA \& PIFKó 2007) a Pilisben is gyakoribb, mint azt korábban hitték (vö. FEICHTINGER 1865, BoRBÁs 1879, Boros 1920, SOMLYAY 2009, $2011 b$ ). Nem kizárt, hogy terjedőben van.

Sonchus palustris L. - B: Budapest: Csillebérc (KFKI-tól ÉNy-ra) [8579.2], Csúcs-hegy [8479.2], Keserűvíztelep (keserűsós rétek) [8580.1], Kőérberek [8579.4, 8580.3], Mocsáros-dűlő [8480.1]; Nagykovácsi: 464 m-es hegytől Ny-ra [8479.3], Kereszt-mező [8479.1], Ördög-árok (az amerikai iskolánál) [8479.1]; Perbál: 471 m-es csúcs környéke [8479.2].

A fenti adatok közül a csillebérci, a csúcs-hegyi és a nagykovácsi erdőirtáshoz, ill. az utóbbiak egy része nádashoz kötődő hegységbeli, a többi alföldi (nádas) előfordulás. KuN (1994) közli Solymár mellől, a Rét-völgy nádasaiból, mint a Budai-hegységre új adatot, itt már 1992-ben gyűjtötte a fajt Felföldy Lajos. A Solymári-völgy azonban növényföldrajzi értelemben az Alföldhöz, ZólYOMI (1958: 512) szemléletes vázlata alapján a Pesti-síkhoz („Pestvidék”) tartozik, hasonlóan a Mocsáros-dűlőhöz (Óbuda) és a Budaörsi-medencéhez (Keserűvíztelephez, Kőérberek). HEGEDÜs (1994) adatai közül is csak egyetlen egy (Hárshegy) tartozik kétségtelenül a Budai-hegységhez, bizonyító példányát nem láttuk.

Sternbergia colchiciflora W. et K. - B: Biatorbágy: Szélkapu-völgy [8579.1] („Kő-hegy”, Felföldy, 1992, BP); Budakeszi: Nagyszénászug [8579.2]; Budaörs: Prékókörnyék [8579.1], Tűzkő-hegy [8579.2]; Budapest: Csillebérc [8579.2], Fazekas-hegy [8479.4], Ferenc-hegy [8480.3] (Boros, 1931, BP), Gellért-hegy [8580.1] (Szép, 1888, BP), Hármashatár-hegy [8479.2] (SADLER 1840, Bohatsch, 1876, BP), Hármashatár-hegy és Újlaki-hegy közti nyereg [8479.2], Pálvölgyi-kőfejtő fölött [8480.3], Tábor-hegy [8480.1, 8480.3] (Boros, 1944, BP), Újlaki-hegy [8479.2] (Jávorka, 1912, BP); Diósd: Felső-Gazdagdűlő [8579.4]. - P: Budakalász: Majdán-hegytől DK-re (Dolinapuszta feletti gerinc) [8379.4], Monalovác-hegy [8380.3]; Budapest (Békásmegyer): Péter-hegy [8480.1] (Boros, Kárpáti Z., 1944, BP), Puszta-domb [8380.3] („Kálváriahegy”, Papp, 1944, BP), Róka-hegy [8480.1] (Trautmann, 1918, BP). - V: Pomáz: Csikóváralja (Kis-Csikóvár) [8379.2] (Degen \& Boros, 1920, BP); Szentendre: Bubán-hegy (Felső-Bubán) [8380.1].

Térségbeli adatait Somlyay $(2009,2011 b)$ tekinti át. A Visegrádi-hegység délkeleti részéről az idézett csikóvárin kívül csak egy régi („in valle retro coemeterium”, Degen, 1924, BP) és 
egy újabb („Kő-hegy”, Kun 1994) pomázi adata ismert. BőHM (2000) a kő-hegyi cikkében ugyan felsorolja a „védett növényfajok" között, a területet tárgyaló részletesebb munkájában (BőHM 2001) már nem említi.

Valerianella coronata (L.) DC. - P: Budapest: Péter-hegy [8480.1]; Csobánka: Kis-Kevély [8379.4] (Boros, 1948, BP), Oszoly [8379.4] (Simonkai, 1903, BP), Ziribár [8379.4]; Pilisborosjenő: Nagy-Kevély [8379.4] (Kárpáti Z., 1948, BP); Pilisszántó - Csobánka: Hosszú-hegy [8379.1, 8379.2]; Üröm: Kő-hegy [8380.3].

Az eddigi adatok szerint e szubmediterrán faj pilisi előfordulásai - hasonlóan a Budaihegységiekhez (SOMLYAY 2009) - a hegység délkeleti részére korlátozódnak, ahol a délies kitettségű, erodálódó löszös sziklagyepekben kedvező években szépen mutatkozik.

Valerianella pumila (L.) DC. - P: Pilisszántó: Hosszú-hegy (a barlang közelében) [8379.2]. Új adat a Pilis hegység flórájára. Az egész országban nagyon ritka faj, amelynek a PilisVisegrádi-hegységből eddig egyetlen biztos, régi adata volt ismert („Messalia”, Jávorka, 1904, BP) (vö. SOMLYAY \& BAUER 2007).

Viola collina Besser - B: Budajenő: Cseresznyés-völgy É-i pereme [8479.1]; Piliscsaba: Csabai-árok [8379.3], Sóder-hegytől É-ra lévő hegy [8379.3]; Pilisvörösvár: Kakukk-hegy (a Kopár-hágónál) [8379.3]. - P: Pilisjászfalu: Nagy-Somlyó [8378.2]; Pilisvörösvár: Fehér-hegy [8379.3], Fehér-hegy és Vörös-hegy közti nyereg [8379.3].

A fentiek kiegészítések SOMLYAY $(2009,2011 b)$ adataihoz.

\section{Köszönetnyilvánítás}

Köszönetünket fejezzük ki Bérces Sándornak és Csáky Péternek (DINPI), Rédei Tamásnak (ÖBI) és Semperger Zsoltnak (Budapest) adataik közlésre történő átengedéséért. Hálásak vagyunk Molnár V. Attilának (Debrecen), aki segített az E. peitzii meghatározásában, az egyik esztergomi Ophrys apifera lelőhelyre felhívta a figyelmünket, és a munkatársaival összeállított magyarországi orchidea-adatbázist rendelkezésünkre bocsátotta. Neki és Óvári Miklósnak (Zalaegerszeg) az Ophrys holubyana meghatározását is köszönjük. Raksányi Zsolt (Budapest) és Tóth György (Gödöllő) a terepi munkákban segítettek. Sulyok Józsefnek (Eger - Felsőtárkány) a Degen-féle Epipactis muelleri példány határozásának megerősítését köszönjük. Az első szerző munkáját az OTKA K108992 számú pályázata támogatta.

\section{Irodalomjegyzék}

BALOGH L. (2011): 150 éve született Márton József, a korabeli Vas megye egyik legjelentősebb herbáriumi gyűjtője. - Botanikai Közlemények 97 (1-2)[2010]: 179.

BARINA Z. (2001): Felhagyott homokbányák florisztikai vizsgálata II. - Kitaibelia 6 (1): 157-165.

BARINA Z. (2009): Adatok a Dunántúli-középhegység és környéke flórájához. - Flora Pannonica 6 [2008]: 3-23.

BARINA Z. \& PIFKó D. (2007): Botanikai kutatások a Visegrádi-hegységben. - Kitaibelia 12 (1): 9-25.

BAUER N. (1996): A dorogi Strázsa-hegy és környékének botanikai értékeiről (Pilis-hegység). - Kanitzia 4: 201-214.

BAUER N. (2001): Vascular flora of the hill Strázsa-hegy and its vicinity (Pilis Mts, Hungary). - Studia botanica hungarica 32: 125-163.

BAUER N. \& BARNA J. (1999): Dorog és Esztergom környékének növényvilága. - BTM, Zirc, 80 pp.

BÁNKUTI K. (2000): A Mátra Múzeum herbáriuma - a Gotthárd-gyűjtemény II. (Dicotyledonopsida: Berberidaceae - Fabaceae). - Folia Historico Naturalia Musei Matraensis 24: 77-93.

Borbás V. (1875): Pestmegye florája Sadler (1840.) óta és ujabb adatok. - Mathematikai és Természettudományi Közlemények [1871] 9: 15-54. 
BorBÁs V. (1879): Budapest és környékének növényzete. - Magyar Királyi Egyetemi Könyvnyomda, Budapest, $172 \mathrm{pp}$.

Boros Á. (1920): Újabb adatok Közép-Magyarország flórájának ismeretéhez. - Botanikai Közlemények 18 (1-6): 39-43.

Boros Á. (1953): A Pilis hegység növényföldrajza. - Földrajzi Közlemények 2 (3): 370-385.

Borsos O. (1959): Geobotanische Monographie der Orchideen der pannonischen und karpatischen Flora II. - Annales Universitatis Scientiarum Budapestinensis 2: 59-93.

Bonsos O. (1960): Geobotanische Monographie der Orchideen der pannonischen und karpatischen Flora IV. - Annales Universitatis Scientiarum Budapestinensis 3: 93-129.

Bonsos 0. (1962): Geobotanische Monographie der Orchideen der pannonischen und karpatischen Flora VI. - Annales Universitatis Scientiarum Budapestinensis 5: 27-61.

Borsos 0. (1963): Geobotanische Monographie der Orchideen der pannonischen und karpatischen Flora VII. - Annales Universitatis Scientiarum Budapestinensis 6: 43-81.

BőHm É. I. (2000): A Szentendre és Pomáz közötti Kőhegy és a környező dombvidék florisztikai vizsgálata; védett növényei és élőhelyei napjainkban. - Lippay János \& Vas Károly Tudományos Ülésszak előadás- és poszterkivonatok. SZIE KK, Budapest, pp. 16-17.

BőHм É. I. (2001): Florisztikai vizsgálatok a Duna-Ipoly Nemzeti Park dél-délkeleti peremén. Kitaibelia 6 (1): 51-71.

BőHM É. I. \& FACSAR G. (1999): Pilisszentkereszt és a Pilis hegy florisztikai vizsgálatának első eredményei Borbás V. (1879) Budapestnek és környékének flórája nyomán. - Természetvédelmi Közlemények 8: $5-36$.

CSÁBI M. \& HALÁSZ A. (2016): Új orchideafaj a magyar flórában: Epipactis pseudopurpurata Mered'a. Kitaibelia 21 (1): 27-32.

Csontos P. \& LőKÖs L. (1992): Védett edényes fajok térbeli eloszlás-vizsgálata a Budai hg. dolomitvidékén - Szünbotanikai alapozás természetvédelmi területek felméréséhez. - Botanikai Közlemények 79 (2): 121-143.

Dовоцүі K. (2004): Az Iváni-hegy (Budai-hg.) botanikai értékei. - Aktuális flóra- és vegetációkutatás a Kárpát-medencében VI., előadások és poszterek összefoglalói, Veszprémi Egyetem Georgikon MTK, Növénytani és Növényélettani Tanszék, Keszthely, p. 68.

Dobolyı K., Kézdy P., Kun A. \& SzABó F. (2008): A Szénás-hegycsoport edényes flórája. - In: Dobolyı K. \& KÉZDY P. (szerk.), Természetvédelem és kutatás a Szénás-hegycsoporton, Duna-Ipoly Nemzeti Park Igazgatóság, Budapest, pp. 169-232.

Dobolyi K., Kováts D., SZERdAhelyi T. \& Szollát Gy. (1991): Vegetation studies on the rocky grasslands of Odvas Hill (Budaörs, Hungary). - Annales historico-naturales Musei nationalis hungarici 83: 199-223.

ENTZ G. (1868): Buda-Pest virányának két uj növénye. - A magyar orvosok és természetvizsgálók Rimaszombatban tartott XII. nagygyúlésének történeti vázlata és munkálatai, Pest, p. 330.

FEICHTINGER S. (1865): Közlemények Esztergom megye helyrajzából. - A magyar orvosok és természetvizsgálók Maros-Vásárhelytt tarott X. nagygyúlésének történeti vázlata és munkálatai, Pest, pp. 273-285.

FEICHTINGER S. (1899): Esztergom megye és környékének flórája. - Esztergom-vidéki Régészeti és Történelmi Társulat, Esztergom, 456 pp.

HAHN I. (2012): Budakalász helyi jelentőségű védett területeinek botanikai értékei. - Kitaibelia 17 (1): 100.

HEGEDÜs Á. (1994): Budapest jelenlegi virágos flórája. - Animula Kiadó, Budapest, 68 pp.

HERMANN G. (1885): Adatok Magyarország flórájához. - Természetrajzi Füzetek 9 (3-4): 280-282.

Holub J. (1972): Neue oder wenig bekannte Pflanzen der ungarischen Flora. - Annales Universitatis Scientiarum Budapestinensis 14: 91-104.

Jávorka S. (1904): Adatok a Pilis-hegység növényzetének ismeretéhez. - Növénytani Közlemények 3 (3): 119-120.

KÁRPÁTI Z. (1947): Megjegyzések és adatok Budapest és környékének flórájához. - Borbásia 7 (1-6): 45-57.

Kecskés F. (1994): A Tétényi-fennsík botanikai értékei. - In: Simon T. (szerk.), Természeti kincsek DélBudán. A Tétényi-fennsík és a Háros-sziget növény- és állatvilága, természetvédelme, Cserépfalvi Kiadó - Zöld jövő, Budapest, 94 pp. + I-VIII. tábla.

KeCSKÉs F. \& Kun A. (2004): A Tétényi-fennsík védett és regionálisan ritka, védendő növényfajai. Aktuális flóra- és vegetációkutatás a Kárpát-medencében VI., előadások és poszterek összefoglalói. Veszprémi Egyetem Georgikon MTK, Növénytani és Növényélettani Tanszék, Keszthely, p. 47. 
KERNER A. (1877a): Die Vegetations-Verhältnisse des mittleren und östlichen Ungarns und angrenzenden Siebenbürgens 92. - Oesterreichische Botanische Zeitschrift 27 (5): 160-164.

KERNER A. (1877b): Die Vegetations-Verhältnisse des mittleren und östlichen Ungarns und angrenzenden Siebenbürgens 93. - Oesterreichische Botanische Zeitschrift 27 (6): 199-204.

KÉZDY P. \& TímÁr G. (1999): Henye boroszlán - Daphne cneorum L. - Tilia 7: 111-125.

Kun A. (1994): Észrevételek és új adatok a Dunazug-hegyvidék növényzetéről. - Botanikai Közlemények 81 (2): 177-181.

Kun A. (1996a): Kiegészítések és újabb adatok a magyar flóra és vegetáció ismeretéhez. - Kitaibelia 1: 26-33.

Kun A. (1996b): Sziklagyepek és lejtősztyeppek a középdunai flóraválasztó környékén I. - Botanikai Közlemények 83 (1-2): 25-38.

Kun A. (1998): Sziklai növénytársulások az Érd-Tétényi-fennsíkon. - Kitaibelia 3: 65-70.

Kun A. (2010): „Hadiállapot” a Tétényi-fennsíkon. - In: MolnÁr Cs., MolnÁR Zs. \& VARGA A. (szerk.), „Hol az a táj szab az életnek teret, Mit az Isten csak jókedvében teremt.” Válogatás az első tizenhárom MÉTA-túrafüzetból 2003-2009. MTA ÖBKI, pp. 199-204.

MAgos G., URbán L. \& SRAmkó G. (2012): Néhány adat a Mátra és környéke edényes flórájának ismeretéhez. - Kitaibelia 17 (1): 114.

Макошsку, А. (1855): Eine Excursion am Blocks- und Adlerberge bei Ofen. - Oesterreichisches Botanisches Wochenblatt 5 (27): 209-211.

MÁthé A., VidÉKi R. \& MolnÁr V. A. (2011): Poloskaszagú sisakoskosbor. - In: MolnÁr V. A. (szerk.), Magyarország orchideáinak atlasza. Kossuth Kiadó, Budapest, pp. 401-403.

MÉszáros A., SulYoK J., VidÉKi R. \& Molnár V. A. (2011): Vöth-nőszőfü. - In: Molnár V. A. (szerk.), Magyarország orchideáinak atlasza. Kossuth Kiadó, Budapest, pp. 231-232.

MolnÁr V. A. (2000): Orchidaceae - Kosborfélék családja. - In: SIMON T., A magyarországi edényes flóra határozója, Harasztok - virágos növények. 4. ed., Tankönyvkiadó, Budapest, pp. 705-725.

Molnár V. A. (2003): Az Epipactis Zinn. Nemzetség fajai Magyarországon. - Flora Pannonica 1: 44-57.

MolnÁR V. A. (2009): Orchidaceae - Kosborfélék családja. - In: KiRÁLY G. (szerk.), Új magyar füvészkönyv. Aggteleki Nemzeti Park Igazgatóság, Jósvafö, pp. 571-583.

MolnáR V. A. (szerk.) (2011a): Magyarország orchideáinak atlasza. - Kossuth Kiadó, Budapest, 504 pp.

Molnár V. A. (2011b): Piros madársisak. - In: Molnár V. A. (szerk.), Magyarország orchideáinak atlasza. Kossuth Kiadó, Budapest, pp. 193-196.

Molnár V. A. (2011c): Agár sisakoskosbor. - In: Molnár V. A. (szerk.), Magyarország orchideáinak atlasza. Kossuth Kiadó, Budapest, pp. 395-398.

MolnÁR V. A. \& GulYÁs G. (2005): Zur Kenntnis der Ophrys holubyana Andrasovszky 1917. - Journal Europäischer Orchideen 37: 625-638.

MolnÁR V. A. \& IllyÉs Z. (2011): Ibolyás gérbics. - In: MolnÁR V. A. (szerk.), Magyarország orchideáinak atlasza. Kossuth Kiadó, Budapest, pp. 267-271.

MolnÁR V. A., SUlYOK J. \& VidÉKI R. (1995): Vadon élő orchideák. - Kossuth Könyvkiadó, Budapest, 160 pp.

ÓvÁRI M. \& Molnár V. A. (2011): Méhbangó. - In: Molnár V. A. (szerk.), Magyarország orchideáinak atlasza. Kossuth Kiadó, Budapest, pp. 408-411.

PAPP J. (1977): A budai Sashegy élővilága. - Akadémiai Kiadó, Budapest, 99 pp.

Pinke Gy. \& PÁL R. (2005): Gyomnövények eredete, termőhelye és védelme. - Alexandra, Pécs, 232 pp.

PRISZTER Sz. (1985): A magyar flóra és vegetáció rendszertani-növényföldrajzi kézikönyve VII. Akadémiai Kiadó, Budapest, 683 pp.

RAKSÁNYI Zs. (1999): Az Ophrys apifera Huds. a Pilisben. - Kitaibelia 4 (1): 204.

Rоватsсн K. (1993): Epipactis voethii K. Robatsch, spec. nova, eine neue Epipactis-Art aus Niederösterreich. - Mitteilungen der Abteilung für Botanik am Landesmuseum "Joanneum" in Graz 21/22: 21-26.

SADLER J. (1818): Verzeichniss der um Pesth und Ofen wildwachsenden phanerogamischen Gewächse. Pesth, $79 \mathrm{pp}$.

SADLER J. (1826): Flora comitatus Pestiensis 2. - Pestini, 399 pp.

SADLER J. (1840): Flora comitatus Pesthinensis. Ed. 2. - Pesthini, 499 pp.

Seymann V. (1908): A Daphne Cneorum L. két újabb lelőhelye Budapest környékén. - Magyar Botanikai Lapok 7: 244-245.

Simon T. (1992): A magyarországi edényes flóra határozója, Harasztok - virágos növények. Tankönyvkiadó, Budapest, 892 pp. 
Simon T. (2000): A magyarországi edényes flóra határozója, Harasztok - virágos növények. 4. ed. Tankönyvkiadó, Budapest, 976 pp.

SimonKAI L. (1876): Adatok Magyarhon edényes növényeihez. Jelentés a Duna jobbparti vidékén tett utazásomról. - Mathematikai és Természettudományi Közlemények 11 (6)[1873]: 157-211.

SomLYAY L. (2000): Adatok a Dunazug-hegység, a Tornai-karszt és környéke flórájához. - Kitaibelia 5: 47-52.

SOMLYAY L. (2009): A Budai-hegység florisztikai növényföldrajzának fő vonásai. - Kitaibelia 14 (1): 35-68.

SomLyay L. (2010): Epipactis futakii (Orchidaceae), a new species for the Hungarian flora. - Ann. hist.nat. Mus. nat. hung. 102: 21-24.

Somlyay L. (2011a): Distribution of Conringia austriaca (Brassicaceae) in Hungary and its phytogeographical significance in Central Europe. - Annales historico-naturales Musei nationalis hungarici 103: 5-22.

SoMLYAY L. (2011b): Adatok Budapest környéke flórájának ismeretéhez. - Kitaibelia 15 (1-2)[2010]: 101-108.

SOMLYAY L. \& BAUER N. (2007): Distribution of a little known plant species, Valerianella pumila in Hungary. - Studia botanica hungarica 38: 143-153.

SomlYAY L. \& PifKó D. (2002): A Lathyrus pallescens (Bieb.) C. Koch Magyarországon, és más adatok a Budai-hegység flórájának ismeretéhez. - Kitaibelia 7 (2): 237-245.

Soó R. (1928): Kritikai megjegyzések III. - Botanikai Közlemények 25 (5-6): 133-146.

Soó R. (1968, 1973, 1980): A magyar flóra és vegetáció rendszertani-növényföldrajzi kézikönyve III., $V$., VI. - Akadémiai Kiadó, Budapest, 506 pp., 724 pp., 557 pp.

Soó R. \& BoRsos O. (1966): Geobotanische Monographie der Orchideen der pannonischen und karpatischen Flora IX. - Annales Universitatis Scientiarum Budapestinensis 8: 315-336.

Soó R. \& ENDRőDY-KovÁCs É. (1966): Über einige Formenreise der ungarischen und karpatischen Flora III. Aquilegia. - Annales Universitatis Scientiarum Budapestinensis 8: 301-308.

SulYoK J. \& MolnÁR V. A. (2011a): Müller-nőszőfü. - In: MolnáR V. A. (szerk.), Magyarország orchideáinak atlasza. Kossuth Kiadó, Budapest, pp. 235-237.

SulYoK J. \& MolnÁR V. A. (2011b): Csőrös nőszőfü. - In: MolnáR V. A. (szerk.), Magyarország orchideáinak atlasza. Kossuth Kiadó, Budapest, pp. 241-243.

SULYOK J., VIDÉKI R. \& MolNÁR A. (1998): Adatok a magyarországi Himantoglossum-fajok ismeretéhez. Kitaibelia 3 (2): 223-229.

Sulyok J., Voigt W., Mészáros A., Somlyay L., Bauer N. \& Molnár V. A. (2011): Keskenyajkú nőszőfü. - In: MolnÁR V. A. (szerk.), Magyarország orchideáinak atlasza. Kossuth Kiadó, Budapest, pp. 245-246.

SZERÉNYI J. (2000): Adatok az Észak-Mezőföld löszflórájához. - Kitaibelia 5 (2): 249-270.

SZERÉNYI J., KÁLLAYNÉ (2014): Értékes növényzetfoltok az érd-sóskúti szarmata mészkövön. - In: SchMIDT D., Kovács M. \& BARTHA D. (szerk.), Aktuális flóra- és vegetációkutatás a Kárpát-medencében X., előadások és poszterek összefoglalói, NYME Erdőmérnöki Kar, Növénytani és Természetvédelmi Intézet, Sopron, pp. 160-161.

SZERÉNYI J. \& KÁLLAY M. (2000): A vitézvirág (Anacamptis pyramidalis Rich.) új lelőhelye a Budaihegységben. - Kitaibelia 5 (1): 227.

SzoLLÁT Gy. (2007): Adatok a Szabadság-hegy félszáraz irtásrétjeinek flórájához. - Kanitzia 14 [2006]: 95-108.

Tóth Z. \& PAPP L. (2012): A budai Sas-hegy edényes flórája. - In: KÉZdY P. \& Tóth Z. (szerk.), Természetvédelem és kutatás a budai Sas-hegyen, DINPI, Budapest, pp. 189-224.

VidÉKi R., SulYoK J. \& Molnár V. A. (2011): Tallós-nőszőfü. - In: Molnár V. A. (szerk.), Magyarország orchideáinak atlasza. Kossuth Kiadó, Budapest, pp. 254-256.

Zólyoмı B. (1958): Budapest és környékének természetes növénytakarója. - In: PÉcsi M. (ed.): Budapest természeti képe, Akadémiai Kiadó, Budapest, pp. 509-642.

ZsáK Z. (1916): Az Epipactis microphylla (Ehrh.) Sw. Pest-megyei újabb előfordulása. - Magyar Botanikai Lapok 15: 272-273.

Zsák Z. (1941): Florisztikai adatok a hazai növényvilág ismeretéhez. - Botanikai Közlemények 38 (1-2): 12-34.

Beérkezett / received: 2016. 03. 04. • Elfogadva / accepted: 2016. 07. 03. 